\title{
Systemic Inflammatory Response to Different Sclerosing Agents as a Predictor of Pleurodesis Outcome
}

\author{
ROLANDAS ZABLOCKIS ${ }^{1,2}$, EDVARDAS DANILA ${ }^{1,2}$, \\ VYGANTAS GRUSLYS ${ }^{1,2}$ and GIEDRE் CINCILEVIČIUTTE் ${ }^{1,2}$ \\ ${ }^{1}$ Clinic of Chest Diseases, Immunology and Allergology, \\ Institute of Clinical Medicine, Vilnius University, Vilnius, Lithuania; \\ ${ }^{2}$ Centre of Pulmonology and Allergology, Santaros Klinikos, Vilnius University Hospital, Vilnius, Lithuania
}

\begin{abstract}
Background/Aim: The objectives of this study were to evaluate systemic inflammation using different sclerosing agents and to estimate the prediction of systemic inflammation for the efficacy of pleurodesis. Patients and Methods: Ninetysix patients with recurrent and symptomatic malignant pleural effusion were enrolled in this retrospective study. We used serum $C$-reactive protein (CRP) levels, serum leukocyte counts and neutrophil-to-lymphocyte ratios (NLRs) as parameters of systemic inflammatory reactions. Evaluations of these parameters were performed before and $24 \mathrm{~h}$ after pleurodesis. Results: Pleurodesis was successful in 81 (84.4\%) patients. The non-graded talc induced the highest changes in serum CRP levels, total white blood cell and neutrophil counts compared to other agents, while mitoxantrone induced the lowest. Graded talc and bleomycin induced the same levels of changes in serum CRP levels and serum leukocyte counts. The change in serum NLR was the same for all agent groups. Logistic regression confirmed that a change in serum CRP levels [odds ratio $(O R)=0.92, p=0.002]$ and previous chemotherapy $(O R=3.31, \quad p=0.012)$ were independent predictors of pleurodesis efficacy. Conclusion: Pleurodesis agents induced a systemic inflammatory response at different levels. The change in serum CRP levels could be useful for predicting the success of pleurodesis.
\end{abstract}

Approximately half of all patients with metastatic cancer develop malignant pleural effusion (MPE), which is likely to

This article is freely accessible online.

Correspondence to: Rolandas Zablockis, MD, Ph.D., Centre of Pulmonology and Allergology, Vilnius University Hospital Santaros Klinikos, Santariskiu str. 2, 08661 Vilnius, Lithuania. Tel: +37 068775633, Fax: +37 02365077, email: rolandas.zablockis@gmail.com

Key Words: malignant pleural effusion, pleurodesis, systemic inflammation, predictive factor. lead to a significant reduction in their quality of life, secondary to symptoms such as dyspnoea and cough (1). The main goals of MPE treatment are to decrease symptoms and improve quality of life (2). Pleurodesis with chemical agents is the most commonly used treatment for MPE (3). Talc is the most frequently used sclerosing agent (4). Nevertheless, talc pleurodesis can manifest some severe complications, such as hypoxia and acute respiratory distress syndrome (5-9). These complications are less frequent after the use of talc with large particles (10-13). Other agents, such as tetracycline derivates, silver nitrate, povidone-iodine, mitoxantrone, doxycycline and bleomycin have also been used, with variable efficacy and safety (14). The search for the most effective and safe agent for chemical pleurodesis is ongoing (15).

Pleurodesis involves the induction of acute pleural inflammation, which, if sufficiently intense, progresses to pleural fibrosis that obliterates the pleural cavity and prevents the reaccumulation of fluid (16). The inflammatory mechanisms involved in this process are not yet fully understood. The manifested inflammatory reaction can be divided into a systemic and local response. The intensity of inflammatory activity in the pleural cavity may predict the efficacy of pleurodesis (17). However, there is a lack of research comparing systemic inflammation induced by different sclerosing agents.

The objectives of this study were to evaluate the systemic inflammation induced by different sclerosing agents in patients with MPE and to predict systemic inflammation in order to determine pleurodesis efficacy.

\section{Patients and Methods}

Study population. A total of 96 consecutive patients who underwent chemical pleurodesis for recurrent and symptomatic MPE in our department from January 2014 to July 2020 were retrospectively selected. Patients with trapped lung, loculated pleural effusion or active pleural or systemic infection were excluded from the study.

All methods were carried out in accordance with the Declaration of Helsinki. The study was approved by the Vilnius Regional Biomedical 
in vivo $35: 2391-2398(2021)$

Table I. Characteristics of the patients according to pleurodesis agents.

\begin{tabular}{|c|c|c|c|c|c|}
\hline Characteristics & $\begin{array}{l}\text { Non-graded talc } \\
\quad(\mathrm{N}=30)\end{array}$ & $\begin{array}{l}\text { Graded talc } \\
\qquad(\mathrm{N}=26)\end{array}$ & $\begin{array}{c}\text { Bleomycin } \\
(\mathrm{N}=24)\end{array}$ & $\begin{array}{l}\text { Mitoxantrone } \\
\quad(\mathrm{N}=16)\end{array}$ & $p$-Value \\
\hline Age, years & $64.5 \pm 10.2$ & $68.4 \pm 5.5$ & $64.5 \pm 14.9$ & $67.0 \pm 8.1$ & 0.437 \\
\hline Gender, $\%$ & & & & & 0.271 \\
\hline Male & 40.0 & 53.8 & 50.0 & 25.0 & \\
\hline Female & 60.0 & 46.2 & 50.0 & 75.0 & \\
\hline Primary cancer, $\%$ & & & & & 0.167 \\
\hline Lung & 40.0 & 43.8 & 50.0 & 43.8 & \\
\hline Breast & 20.0 & 13.9 & 8.3 & 12.5 & \\
\hline Others & 40.0 & 42.3 & 41.7 & 43.7 & \\
\hline LENT score categories, $\%$ & & & & & 0.064 \\
\hline Low or moderate risk & 30.7 & 28.6 & 21.4 & 19.3 & \\
\hline High risk & 20.0 & 25.0 & 30.0 & 25.0 & \\
\hline Previous chemotherapy, $\%$ & 86.7 & 53.8 & 75.0 & 62.5 & 0.056 \\
\hline Previous thoracentesis, number & $1.5 \pm 1.9$ & $1.2 \pm 0.7$ & $1.6 \pm 1.3$ & $1.9 \pm 1.7$ & 0.491 \\
\hline Total amount of PF, litres & $3.7 \pm 2.0$ & $3.2 \pm 1.1$ & $3.3 \pm 2.4$ & $3.9 \pm 1.6$ & 0.547 \\
\hline Positive PF cytology, $\%$ & 71.4 & 69.2 & 83.3 & 62.5 & 0.501 \\
\hline CRP level, mg/l & $24.0 \pm 22.7$ & $36.4 \pm 38.4$ & $40.1 \pm 30.4$ & $33.6 \pm 31.4$ & 0.263 \\
\hline WBC count, per $\mathrm{mm}^{3}$ & $7.1 \pm 3.1$ & $6.6 \pm 1.9$ & $7.1 \pm 2.9$ & $6.8 \pm 2.9$ & 0.944 \\
\hline Neutrophil count, per $\mathrm{mm}^{3}$ & $5.0 \pm 2.7$ & $4.5 \pm 1.6$ & $5.0 \pm 2.9$ & $5.1 \pm 2.8$ & 0.860 \\
\hline Lymphocyte count, per $\mathrm{mm}^{3}$ & $1.3 \pm 0.5$ & $1.2 \pm 0.6$ & $1.2 \pm 0.4$ & $0.9 \pm 0.3$ & 0.062 \\
\hline Monocyte count, per $\mathrm{mm}^{3}$ & $0.6 \pm 0.2$ & $0.7 \pm 0.2$ & $0.6 \pm 0.3$ & $0.6 \pm 0.2$ & 0.146 \\
\hline NLR & $4.1 \pm 2.5$ & $4.3 \pm 2.4$ & $4.7 \pm 3.1$ & $7.7 \pm 9.2$ & 0.059 \\
\hline Efficacy of pleurodesis, $\%$ & 93.3 & 88.5 & 88.3 & 62.5 & 0.046 \\
\hline \multicolumn{6}{|l|}{ Side effects of pleurodesis, $\%$} \\
\hline Oxygen desaturation or respiratory failure & 6.7 & 3.8 & 4.2 & 0.0 & 0.094 \\
\hline Fever & 32.1 & 28.6 & 26.8 & 25.9 & 0.267 \\
\hline Chest pain & 22.5 & 20.2 & 19.8 & 21.4 & 0.462 \\
\hline
\end{tabular}

Data are presented as the means \pm standard deviation $(\%)$ or number $(\%)$. Significant values are shown in bold. PF, Pleural fluid; CRP, C reactive protein; WBC, white blood cell; NLR, neutrophil-to-lymphocyte ratio.

Ethics Committee (no. 158200-13-652-210), Vilnius, Lithuania. Written informed consent for participation was obtained from each patient.

Data collection. Data relating to demographic characteristics, pleural fluid parameters and blood sample evaluations were obtained from the medical records. Performance status (PS) was estimated using the Eastern Cooperative Oncology Group (ECOG) scale (18). The prognosis of patients was determined using the LENT (pleural fluid lactate dehydrogenase, ECOG PS score, neutrophil-to-lymphocyte ratio and tumour type) scoring system (19). We used serum C-reactive protein (CRP) levels, white blood cell (WBC) counts, neutrophil, lymphocyte counts, monocyte counts and the neutrophil-to-lymphocyte ratio (NLR) as surrogate markers for systemic inflammation. Serum leukocyte and CRP evaluations were performed immediately before and $24 \mathrm{~h}$ after pleurodesis. The efficacy of pleurodesis was evaluated 30 days after the procedure according to Paladine's criteria (20) as follows: complete response (no pleural effusion detected); partial response (minimal pleural fluid detected without the need for repeat thoracentesis or drainage); no response (reaccumulation of pleural fluid causing symptoms or requiring additional pleural procedures). Complete and partial responses were defined as successful pleurodesis.

Pleurodesis technique. A dose of 5 grams of sterile, non-graded talc (Gintarine vaistine, Lithuania), $60 \mathrm{mg}$ of bleomycin (Medac,
Germany) or $40 \mathrm{mg}$ of mitoxantrone (Baxter, Germany) in $100 \mathrm{ml}$ of normal saline was instilled after pleural drainage. A dose of 4 grams of sterile, graded talc (Steritalc ${ }^{\circledR}$ F4, Novatech, France) was applied thoracoscopically (poudrage). A chest tube (24F) was clamped for 4 hours and only afterwards connected to the gravity drainage. The drainage systems were removed when the daily pleural fluid drainage volume was less than $100 \mathrm{ml}$.

Statistical analysis. Chi-squared test, Fisher's exact test, and oneway analysis of variance (ANOVA) followed by the post hoc least significant difference (LSD) test were used for comparison between the pleurodesis treatment groups. Binary logistic regression analysis was performed to determine which independent factors had a significant impact on the success of pleurodesis. Receiver operating characteristic (ROC) curve analysis was used to estimate the sensitivity and specificity of the parameters and cut-off value. A $p$-Value $<0.05$ was defined as statistically significant. The data were analyzed using SPSS version 21.0 (IBM Corp., Armonk, NY, USA).

\section{Results}

Basic characteristics of the study population. Forty-two $(43.7 \%)$ patients were male and $54(56.3 \%)$ were female. 

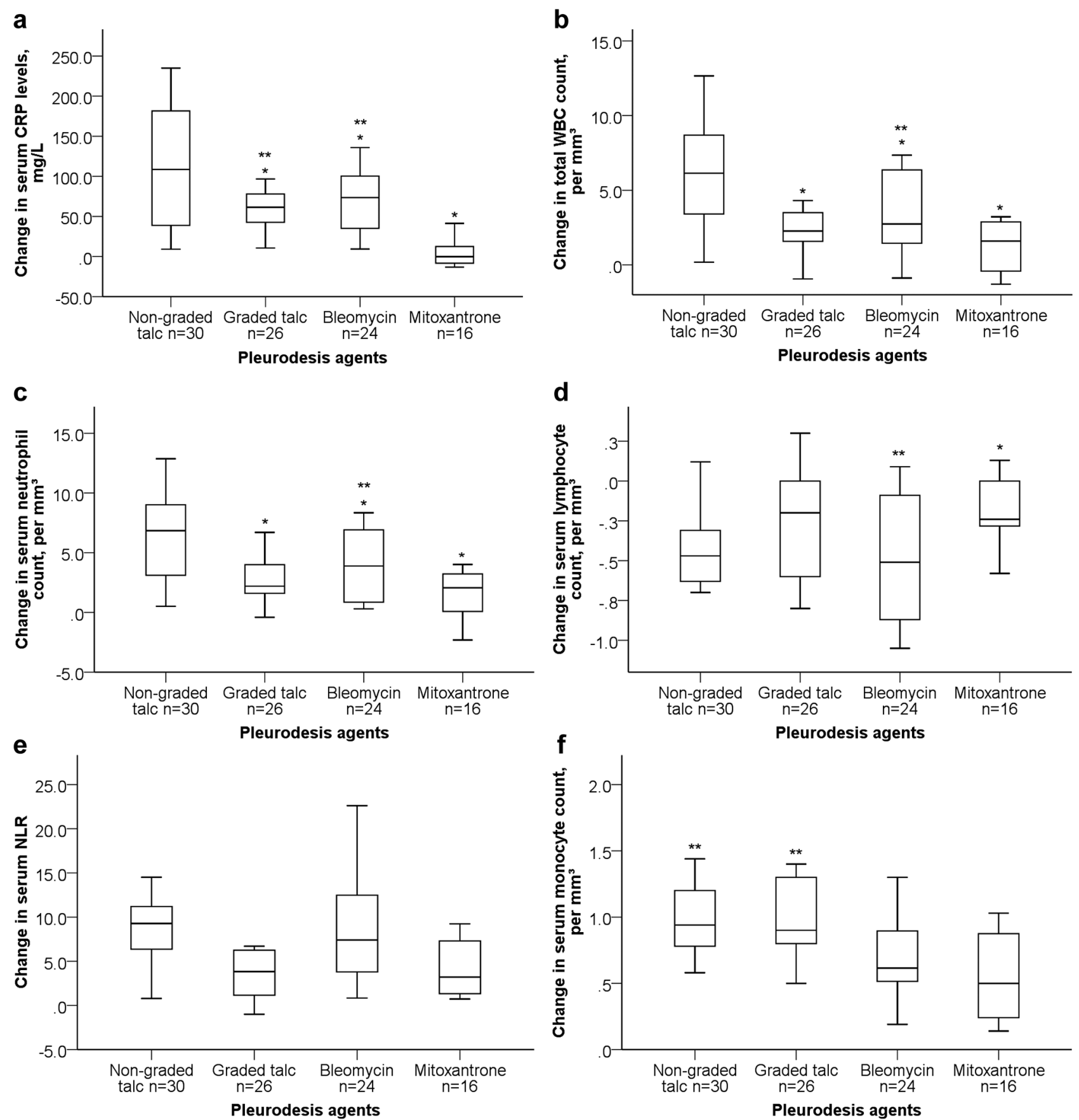

Figure 1. Changes in serum CRP level. (a), total WBC count (b), neutrophil count (c), lymphocyte count (d), monocyte count (e) and the NLR (f) $24 \mathrm{~h}$ after pleurodesis. Data are shown as the minimum, maximum, median, and first and third quartiles. Significant differences of $p<0.05 \mathrm{vs.} *$ Nongraded talc, **Mitoxantrone. CRP, C reactive protein; WBC, white blood cell; NLR, neutrophil-to-lymphocyte ratio.

The median patient age was 64 years (ranging from 44 to 85 years). The characteristics of the population according to pleurodesis agents are shown in Table I. The majority $(87.5 \%)$ of patients had LENT scores $\leq 2$ (low or moderate risk), and just over half (54.2\%) of the patients had an
ECOG PS of 2-3. The primary cancers were lung cancer $(41.7 \%)$, breast $(13.5 \%)$, ovarian $(10.4 \%)$, gastrointestinal $(8.4 \%)$, lymphoma $(8.3 \%)$, kidney $(6.3 \%)$, uterus $(2.1 \%)$, and others $(9.4 \%)$. No one had malignant mesothelioma. The results of the pleural fluid cell block were positive in $72.3 \%$ 
Table II. Patient characteristics according to the efficacy of pleurodesis at 30 days.

\begin{tabular}{lccc}
\hline Characteristics & $\begin{array}{c}\text { Successfull } \\
\text { pleurodesis } \\
(\mathrm{N}=81)\end{array}$ & $\begin{array}{c}\text { Failed } \\
\text { pleurodesis } \\
(\mathrm{N}=15)\end{array}$ & $p$-Value \\
& $66.1 \pm 10.1$ & $65.2 \pm 11.5$ & 0.766 \\
\hline Age, years & & & 0.051 \\
Gender, $\%$ & 48.1 & 20.0 & \\
Male & 51.9 & 80.0 & \\
Female & & & 0.586 \\
Primary cancer & 84.4 & 15.6 & \\
$\quad$ Lung & 92.9 & 7.1 & 0.090 \\
$\quad$ Breast & 81.1 & 18.9 & \\
$\quad$ Others & 90.1 & 73.3 & \\
LENT score categories, \% & 9.9 & 26.7 & \\
Low or moderate risk & 75.3 & 46.7 & 0.053 \\
High risk & $1.4 \pm 1.4$ & $1.8 \pm 1.6$ & 0.308 \\
Previous chemotherapy, \% & $3.4 \pm 1.6$ & $3.8 \pm 2.5$ & 0.456 \\
Previous thoracentesis, number & 73.4 & 66.7 & 0.753 \\
Total amount of PF, liters & & & \\
Positive PF cytology, \% & & & \\
\hline
\end{tabular}

Data are presented as the means \pm standard deviation $(\%)$ or number $(\%)$. PF, Pleural fluid.

of cases. All other cases of malignant pleural effusion were diagnosed via pleural biopsy.

The efficacy and side effects of pleurodesis. Pleurodesis was successful $(39.6 \%$ and $44.8 \%$ for complete and partial responses, respectively) in $81(84.4 \%)$ patients. Talc was the most effective $(91.1 \%, p=0.046)$ agent compared to other sclerosing agents (bleomycin $88.3 \%$ and mitoxantrone $62.5 \%$ ). The difference in the response rates of non-graded talc and graded talc was nonsignificant $(93.3 \%$ vs. $88.5 \%)$. We found no significant differences in the incidence of fever, chest pain, oxygen desaturation or respiratory failure between pleurodesis agents. In addition, pleural empyema, wound infection or death were not reported in any patients.

Systemic inflammatory response. The changes in serum CRP levels, total WBC, neutrophil and lymphocyte counts, monocyte counts and the neutrophil-to-lymphocyte ratio at $24 \mathrm{~h}$ after pleurodesis are presented in Figure 1.

The non-graded talc induced the largest changes in serum CRP levels, total WBC and neutrophil counts compared to other agents, while mitoxantrone induced the smallest changes. Graded talc and bleomycin induced changes in serum CRP levels and total WBC, neutrophil, granulocyte, lymphocyte, and monocyte counts to the same extent. The change in serum NLR was the same for all agent groups.

Predictors of pleurodesis success. The characteristics of the patients according to the efficacy of pleurodesis at 30 days
Table III. Patient characteristics according to the efficacy of pleurodesis at 30 days.

\begin{tabular}{|c|c|c|c|}
\hline Characteristics & $\begin{array}{c}\text { Successfull } \\
\text { pleurodesis } \\
\quad(\mathrm{N}=81)\end{array}$ & $\begin{array}{c}\text { Failed } \\
\text { pleurodesis } \\
(\mathrm{N}=15)\end{array}$ & $p$-Value \\
\hline $\mathrm{CRP}$ at baseline, $\mathrm{mg} / \mathrm{dl}$ & $32.1 \pm 30.4$ & $37.7 \pm 34.7$ & 0.564 \\
\hline $\begin{array}{l}\text { CRP } 24 \mathrm{~h} \text { after pleurodesis, } \\
\mathrm{mg} / \mathrm{dl}\end{array}$ & $120.5 \pm 72.4$ & $50.6 \pm 51.4$ & $<0.001$ \\
\hline CRP change, $\mathrm{mg} / \mathrm{dl}$ & $79.7 \pm 55.8$ & $12.8 \pm 16.1$ & $<0.001$ \\
\hline $\begin{array}{l}\text { WBC count at baseline, } \\
\text { per } \mathrm{mm}^{3}\end{array}$ & $6.5 \pm 2.6$ & $8.7 \pm 2.7$ & 0.090 \\
\hline $\begin{array}{l}\text { WBC count } 24 \mathrm{~h} \text { after } \\
\text { pleurodesis, per } \mathrm{mm}^{3}\end{array}$ & $10.5 \pm 4.7$ & $10.8 \pm 3.5$ & 0.760 \\
\hline WBC count change, per $\mathrm{mm}^{3}$ & $3.9 \pm 3.4$ & $2.1 \pm 2.8$ & 0.040 \\
\hline $\begin{array}{l}\text { Neutrophil count at baseline, } \\
\text { per } \mathrm{mm}^{3}\end{array}$ & $4.5 \pm 2.3$ & $6.8 \pm 2.7$ & 0.060 \\
\hline $\begin{array}{l}\text { Neutrophil count } 24 \mathrm{~h} \text { after } \\
\text { pleurodesis, per } \mathrm{mm}^{3}\end{array}$ & $8.6 \pm 4.3$ & $9.1 \pm 3.3$ & 0.616 \\
\hline $\begin{array}{l}\text { Neutrophil count change, } \\
\text { per } \mathrm{mm}^{3}\end{array}$ & $4.1 \pm 3.5$ & $2.3 \pm 2.7$ & 0.057 \\
\hline $\begin{array}{l}\text { Lymphocyte count at baseline, } \\
\text { per } \mathrm{mm}^{3}\end{array}$ & $1.2 \pm 0.5$ & $1.1 \pm 0.3$ & 0.174 \\
\hline $\begin{array}{l}\text { Lymphocyte count } 24 \mathrm{~h} \text { after } \\
\text { pleurodesis, per } \mathrm{mm}^{3}\end{array}$ & $0.9 \pm 0.4$ & $0.9 \pm 0.3$ & 0.832 \\
\hline $\begin{array}{l}\text { Lymphocyte count change, } \\
\text { per } \mathrm{mm}^{3}\end{array}$ & $-0.3 \pm 0.3$ & $-0.2 \pm 0.3$ & 0.226 \\
\hline $\begin{array}{l}\text { Monocyte count at baseline, } \\
\text { per } \mathrm{mm}^{3}\end{array}$ & $0.6 \pm 0.2$ & $0.6 \pm 0.2$ & 0.432 \\
\hline $\begin{array}{l}\text { Monocyte count } 24 \mathrm{~h} \text { after } \\
\text { pleurodesis, per } \mathrm{mm}^{3}\end{array}$ & $0.8 \pm 0.4$ & $0.7 \pm 0.5$ & 0.833 \\
\hline $\begin{array}{l}\text { Monocyte count change, } \\
\text { per } \mathrm{mm}^{3}\end{array}$ & $0.2 \pm 0.4$ & $0.1 \pm 0.3$ & 0.260 \\
\hline NLR at baseline & $4.6 \pm 4.8$ & $6.6 \pm 2.7$ & 0.120 \\
\hline NLR $24 \mathrm{~h}$ after pleurodesis & $11.0 \pm 6.3$ & $11.0 \pm 3.7$ & 0.997 \\
\hline NLR change & $6.3 \pm 7.1$ & $4.5 \pm 3.1$ & 0.371 \\
\hline
\end{tabular}

Data are presented as the means \pm standard deviation (\%) or number (\%). Significant values are shown in bold. CRP, C reactive protein; WBC, white blood cell; NLR, neutrophil-to-lymphocyte ratio.

are presented in Table II. The serum inflammatory marker dynamics according to the efficacy of pleurodesis at 30 days are presented in Table III. All variables with a $p$-value of 0.2 or less according to the efficacy of pleurodesis were entered into binary logistic regression analysis (Table IV). The regression model was statistically significant $\left(\chi^{2}=45.7\right.$, $p<0.001)$ and correctly predicted $95.5 \%$ of cases. Nagelkerke's $\mathrm{R}^{2}$ statistic was 0.71 , which indicates that the regression model is good for predictive analytics. Binary logistic regression confirmed that a change in serum CRP levels [odds ratio $(\mathrm{OR})=0.92 ; 95 \%$ confidence interval $(\mathrm{CI})=0.88-0.96, p=0.002]$ and previous chemotherapy $(\mathrm{OR}=3.31 ; 95 \% \mathrm{CI}=2.12-4.21, p=0.012)$ were independent predictors of pleurodesis efficacy. ROC curve analysis revealed that a change in serum CRP levels $24 \mathrm{~h}$ after pleurodesis at a cut-off value of $47 \mathrm{mg} / \mathrm{L}$ yielded $68.8 \%$ 
Table IV. Logistic regression analysis for pleurodesis success.

\begin{tabular}{lcc}
\hline Characteristic & OR (95\% CI) & $p$-Value \\
\hline Gender (male $v s$. female) & $0.06(0.01-16.12)$ & 0.328 \\
Previous chemotherapy (yes $v s$. no) & $3.31(2.12-4.21)$ & $\mathbf{0 . 0 1 2}$ \\
LENT score categories (low or & $0.27(0.04-1.52)$ & 0.137 \\
moderate risk $v$. high risk) & & \\
CRP 24 h after pleurodesis & $0.91(0.81-1.03)$ & 0.150 \\
CRP change & $0.92(0.88-0.96)$ & $\mathbf{0 . 0 0 1}$ \\
WBC count at baseline & $0.03(0.01-14.09)$ & 0.256 \\
WBC count change & $0.03(0.01-13.61)$ & 0.254 \\
Neutrophil count at baseline & $2.11(1.18-3.77)$ & $\mathbf{0 . 0 1 1}$ \\
Neutrophil count change & $1.53(1.02-2.29)$ & $\mathbf{0 . 0 3 9}$ \\
Lymphocyte count at baseline & $0.23(0.01-2.40)$ & 0.193 \\
NLR at baseline & $1.02(0.91-1.15)$ & 0.724 \\
\hline
\end{tabular}

Significant values are shown in bold. CRP, C reactive protein; $\mathrm{WBC}$, white blood cell; NLR, neutrophil-to-lymphocyte ratio; OR, odds ratio; $\mathrm{CI}$, confidence interval.

sensitivity and $93.3 \%$ specificity in identifying successful pleurodesis (Figure 2).

\section{Discussion}

We investigated the systemic inflammatory reaction in patients with MPE following the administration of different chemical agents into the pleura and the predictive factors related to the efficacy of pleurodesis in this study. For pleurodesis to be successful, several conditions have to be considered. A tight and complete apposition between the visceral and parietal pleura is required $(21,22)$. For these reasons, patients with trapped lungs and loculated effusion were excluded from the study.

Among the various pleurodesis agents currently available, talc is the most commonly used sclerosing agent $(23,24)$. The efficacy of talc in the control of MPE was found to be superior to that of bleomycin and mitoxantrone in our study. The frequency of successful pleurodesis with the non-graded talc and graded talc was similar, which is in accordance with previous studies $(1,10,11,25)$. We found no significant differences in the incidence of side effects with different agents.

Previous chemotherapy was an independent predictor of pleurodesis efficacy in our study. The statement of the European Respiratory Society (ERS) and the European Association for Cardio-Thoracic Surgery (EACTS) summarises the evidence regarding the management of MPEs. The statement concludes that at present, there is no robust evidence to support the use of oncological therapies as an alternative to standard palliative procedures for MPE management, although further research is required (26).

The intensity of the systemic inflammatory response was quantified by monitoring serum total WBC, the neutrophil,

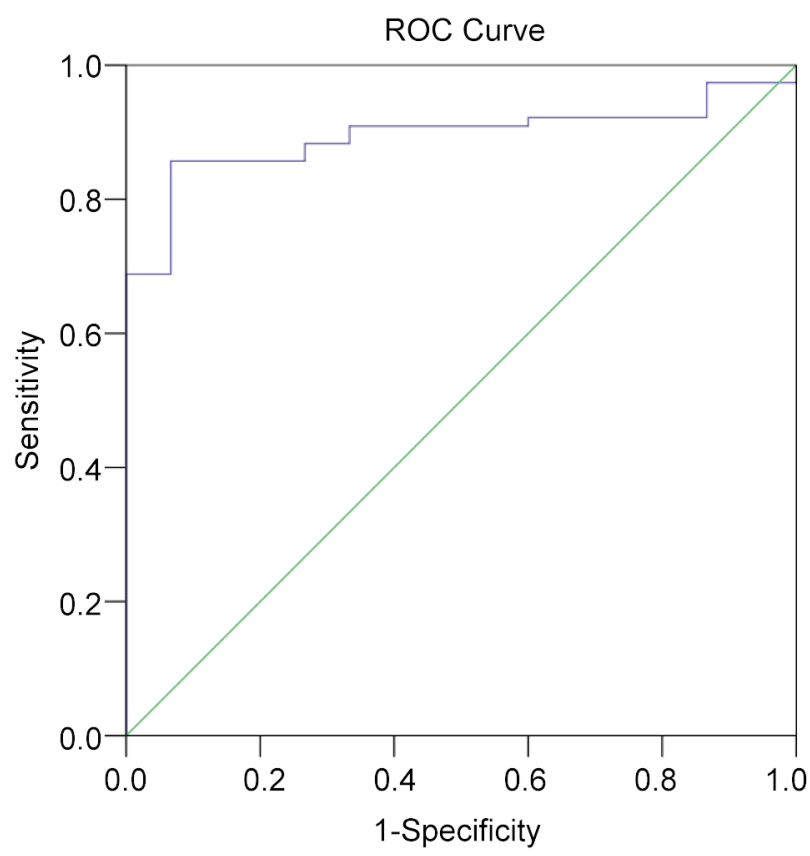

Figure 2. ROC curve of the relationship between CRP and success of pleurodesis. $(A U C=0.89, \quad p=0.002)$. ROC, Receiver operating characteristic; $C R P, C$ reactive protein; $A U C$, area under the curve.

lymphocyte, and monocyte counts, as well as the NLR and CRP levels. Our findings indicate that all pleurodesis agents produced an acute systemic inflammatory response in the first $24 \mathrm{~h}$ of the procedure. An increase in total serum WBC, the neutrophil count and CRP levels and a decrease in the lymphocyte count $24 \mathrm{~h}$ after pleurodesis were observed. The non-graded talc induced the greatest systemic inflammatory response (the highest changes in serum CRP levels, total WBC and neutrophil counts) compared to other pleurodesis agents. Similar findings have been confirmed by previous studies $(6,10,25,27)$.

It is interesting that graded talc and bleomycin induced the same intensity of systemic inflammation, which was more pronounced than that of mitoxantrone in our study. The precise mechanism of action of bleomycin and other antineoplastic agents is not fully understood. Forty-five percent of an intrapleural dose of bleomycin is absorbed into the systemic circulation (28). Accordingly, it may remain in the pleural space only for a short period. One possible advantage of mitoxantrone over bleomycin is that mitoxantrone binds to the membranes of mesothelial cells and is therefore likely to remain longer in the pleural space (29). However, in contrast to previous studies $(30,31)$, in the current study, the efficacy of mitoxantrone in controlling MPE was the lowest, compared to other agents. In addition, mitoxantrone induced the lowest systemic 
inflammatory response (change in serum CRP level) compared to other agents.

Different studies have addressed the predictors of success of pleurodesis for MPE in different clinical settings (17, 32, 33). However, there have been contradictory results. A metaanalysis of 42 studies demonstrated that the strongest predictors of pleurodesis success were higher pleural fluid $\mathrm{pH}$, smaller volume of effusion before pleurodesis and full lung re-expansion after effusion drainage (34). Higher pleural fluid glucose, lower LDH, lower pleural tumour burden, and shorter duration of tube drainage seem to favour pleurodesis success. However, data from these studies were limited by statistical heterogeneity (34). It is not known how well serum biomarkers correlate with pleural inflammation.

Our data indicate a clear positive correlation between the change in serum CRP levels at $24 \mathrm{~h}$ after pleurodesis and the outcome of pleurodesis. The change in serum CRP levels at a cut-off value of $47 \mathrm{mg} / \mathrm{L}$ yielded moderate sensitivity and high specificity for successful pleurodesis.

We found only one study that reported similar findings (35). In this study, a post hoc analysis from the TIME 1 trial was undertaken to establish predictors of pleurodesis success. A total of 320 patients with a diagnosis of MPE who underwent pleurodesis were included. Mercer et al. (35) concluded that inflammation may be a factor in pleurodesis success, as patients with a greater increase in CRP (mean difference: $19.2 \mathrm{mg} / 1$; $95 \% \mathrm{CI}=6.2-32.0 \mathrm{mg} / 1, p=0.004$ ) were more likely to have successful pleurodesis. In this study however, only talc was used for pleurodesis. Some patients with unexpandable lungs were also included, which may explain the lower success rate of talc pleurodesis than that observed in our study $(81.4 \% v s .93 .3 \%$ for non-graded talc and $88.5 \%$ for graded talc).

Mercer et al. (35) incrementally increased the cut-off value of CRP to assess its potential association with pleurodesis success. Using a CRP cut-off of $\geq 30 \mathrm{mg} / 1,84.7 \%$ of patients in the pleurodesis success group met this criterion, compared with $72 \%$ in the pleurodesis failure group $\left(\chi^{2}=4.62, p=0.032\right)$. Although that study showed a statistically significant difference in the change in CRP between the groups, there was no specific cut-off value that could be used to predict pleurodesis success.

Finding biomarkers that predict pleurodesis success can be clinically useful. Our data support the hypothesis that higher levels of systemic inflammation are associated with pleurodesis success. We found that changes in serum CRP can predict pleurodesis success. We did not determine a CRP cut-off value specific to each pleurodesis agent due to the small group sizes. However, this information could be used to plan future research. An indwelling pleural catheter (IPC) is increasingly used as a therapeutic option in patients with MPE (36). The mechanisms underlying pleural inflammation and spontaneous pleurodesis after IPC placement are poorly understood. The pleural fluid cytokines profile may be associated with the outcome of pleurodesis induced by IPCs (37). Pleurodesis stimulates a massive local rise in many proinflammatory cytokines (e.g. interleukin-8) (38-40). It is possible that the measurement of these mediators in blood may better reflect the intensity of pleural inflammation and may be associated with the outcome of pleurodesis $(16,40$, 41). Another limitation of this study is its retrospective design. Nevertheless, the study population was typical of that seen in everyday practice.

In conclusion, the results of this study demonstrate that pleurodesis agents induce a systemic inflammatory response at different levels. Changes in serum CRP levels at $24 \mathrm{~h}$ after pleurodesis could be useful for predicting the success of pleurodesis for patients with MPE. These results should be validated in a prospective study in the future.

\section{Conflicts of Interest}

The Authors explicitly state that there are no conflicts of interest in connection with this article.

\section{Authors' Contributions}

Rolandas Zablockis designed the study, collected and analysed data, wrote the paper; Edvardas Danila critically reviewed the manuscript; Vygantas Gruslys performed the study and critically reviewed the manuscript; Giedre Cincilevičiūtè performed the study and critically reviewed the manuscript.

\section{References}

1 Shaw PH and Agarwal R: WITHDRAWN: Pleurodesis for malignant pleural effusions. Cochrane Database Syst Rev (11): CD002916, 2013. PMID: 24259053. DOI: 10.1002/ 14651858.CD002916.pub3

2 Roberts ME, Neville E, Berrisford RG, Antunes G, Ali NJ and BTS Pleural Disease Guideline Group: Management of a malignant pleural effusion: British Thoracic Society Pleural Disease Guideline 2010. Thorax 65 Suppl 2: ii32-ii40, 2010. PMID: 20696691. DOI: 10.1136/thx.2010.136994

3 Nam HS: Malignant pleural effusion: medical approaches for diagnosis and management. Tuberc Respir Dis (Seoul) 76(5): 211217, 2014. PMID: 24920947. DOI: 10.4046/trd.2014.76.5.211

4 Lee YC, Baumann MH, Maskell NA, Waterer GW, Eaton TE, Davies RJ, Heffner JE and Light RW: Pleurodesis practice for malignant pleural effusions in five English-speaking countries: survey of pulmonologists. Chest 124(6): 2229-2238, 2003. PMID: 14665505. DOI: 10.1378/chest.124.6.2229

5 Azzopardi M, Porcel JM, Koegelenberg CF, Lee YC and Fysh ET: Current controversies in the management of malignant pleural effusions. Semin Respir Crit Care Med 35(6): 723-731, 2014. PMID: 25463163. DOI: 10.1055/s-0034-1395795

6 Campos JR, Werebe EC, Vargas FS, Jatene FB and Light RW: Respiratory failure due to insufflated talc. Lancet 349(9047): 251-252, 1997. PMID: 9014915. DOI: 10.1016/S01406736(05)64860-X 
7 Rehse DH, Aye RW and Florence MG: Respiratory failure following talc pleurodesis. Am J Surg 177(5): 437-440, 1999. PMID: 10365887. DOI: 10.1016/s0002-9610(99)00075-6

8 Janssen JP, Collier G, Astoul P, Tassi GF, Noppen M, RodriguezPanadero F, Loddenkemper R, Herth FJ, Gasparini S, Marquette $\mathrm{CH}$, Becke B, Froudarakis ME, Driesen P, Bolliger CT and Tschopp JM: Safety of pleurodesis with talc poudrage in malignant pleural effusion: a prospective cohort study. Lancet 369(9572): 1535-1539, 2007. PMID: 17482984. DOI: 10.1016/S0140-6736(07)60708-9

9 Montes JF, Ferrer J, Villarino MA, Baeza B, Crespo M and Garcia-Valero J: Influence of talc dose on extrapleural talc dissemination after talc pleurodesis. Am J Respir Crit Care Med 168(3): 348-355, 2003. PMID: 12773332. DOI: 10.1164/ rccm.200207-767OC

10 Maskell NA, Lee YC, Gleeson FV, Hedley EL, Pengelly G and Davies RJ: Randomized trials describing lung inflammation after pleurodesis with talc of varying particle size. Am J Respir Crit Care Med 170(4): 377-382, 2004. PMID: 15142871. DOI: 10.1164/rccm.200311-15790C

11 Genofre EH, Vargas FS, Acencio MM, Antonangelo L, Teixeira LR and Marchi E: Talc pleurodesis: evidence of systemic inflammatory response to small size talc particles. Respir Med 103(1): 91-97, 2009. PMID: 18789662. DOI: 10.1016/j.rmed. 2008.07.021

12 Rossi VF, Vargas FS, Marchi E, Acencio MM, Genofre EH, Capelozzi VL and Antonangelo L: Acute inflammatory response secondary to intrapleural administration of two types of talc. Eur Respir J 35(2): 396-401, 2010. PMID: 19679605. DOI: 10.1183/ 09031936.00039209

13 Arellano-Orden E, Romero-Falcon A, Juan JM, Ocaña Jurado M, Rodriguez-Panadero $F$ and Montes-Worboys A: Small particle-size talc is associated with poor outcome and increased inflammation in thoracoscopic pleurodesis. Respiration 86(3): 201-209, 2013. PMID: 23018589. DOI: 10.1159/000342042

14 Agarwal R, Aggarwal AN and Gupta D: Efficacy and safety of iodopovidone pleurodesis through tube thoracostomy. Respirology 11(1): 105-108, 2006. PMID: 16423210. DOI: 10.1111/j.1440-1843.2006.00792.x

15 Koegelenberg CF and Vorster MJ: Chemical pleurodesis for malignant pleural effusion: How far have we come in 80 years? Respiration 90(5): 355-356, 2015. PMID: 26484756. DOI: $10.1159 / 000441308$

16 Chan JYH and Lee YCG: Pleurodesis and systemic inflammatory markers: Lessons and insights. Respirology 25(7): 676-677, 2020. PMID: 31945800. DOI: 10.1111/resp.13765

17 Habal P, Omran N, Jankovicova K, Krejsek J and Mandak J: Predictive value of systemic and local inflammation parameters in talc pleurodesis assessment. Biomed Pap Med Fac Univ Palacky Olomouc Czech Repub 159(2): 234-241, 2015. PMID: 25059234. DOI: $10.5507 /$ bp.2014.038

18 Oken MM, Creech RH, Tormey DC, Horton J, Davis TE, McFadden ET and Carbone PP: Toxicity and response criteria of the Eastern Cooperative Oncology Group. Am J Clin Oncol 5(6): 649-655, 1982. PMID: 7165009.

19 Clive AO, Kahan BC, Hooper CE, Bhatnagar R, Morley AJ, Zahan-Evans N, Bintcliffe OJ, Boshuizen RC, Fysh ET, Tobin CL, Medford AR, Harvey JE, van den Heuvel MM, Lee YC and Maskell NA: Predicting survival in malignant pleural effusion: development and validation of the LENT prognostic score.
Thorax 69(12): 1098-1104, 2014. PMID: 25100651. DOI: 10.1136/thoraxjnl-2014-205285

20 Paladine W, Cunningham TJ, Sponzo R, Donavan M, Olson K and Horton $\mathrm{J}$ : Intracavitary bleomycin in the management of malignant effusions. Cancer 38(5): 1903-1908, 1976. PMID: 62609. DOI: 10.1002/1097-0142(197611)38:5<1903::aidcncr2820380506>3.0.co;2-a

21 Rodriguez-Panadero F and Montes-Worboys A: Mechanisms of pleurodesis. Respiration 83(2): 91-98, 2012. PMID: 22286268. DOI: $10.1159 / 000335419$

22 Huggins JT, Doelken P and Sahn SA: The unexpandable lung. F1000 Med Rep 2: 77, 2010. PMID: 21173837. DOI: 10.3410/M277

23 Dresler CM, Olak J, Herndon JE 2nd, Richards WG, Scalzetti E, Fleishman SB, Kernstine KH, Demmy T, Jablons DM, Kohman L, Daniel TM, Haasler GB, Sugarbaker DJ, Cooperative Groups Cancer and Leukemia Group B, Eastern Cooperative Oncology Group, North Central Cooperative Oncology Group and Radiation Therapy Oncology Group: Phase III intergroup study of talc poudrage $v s$. talc slurry sclerosis for malignant pleural effusion. Chest 127(3): 909915, 2005. PMID: 15764775. DOI: 10.1378/chest.127.3.909

24 Baiu I, Yevudza E and Shrager JB: Talc pleurodesis: a medical, medicolegal, and socioeconomic review. Ann Thorac Surg 109(4): 1294-1301, 2020. PMID: 31593652. DOI: 10.1016/ j.athoracsur.2019.08.104

25 Tan C, Sedrakyan A, Browne J, Swift S and Treasure T: The evidence on the effectiveness of management for malignant pleural effusion: a systematic review. Eur J Cardiothorac Surg 29(5): 829-838, 2006. PMID: 16626967. DOI: 10.1016/ j.ejcts.2005.12.025

26 Bibby AC, Dorn P, Psallidas I, Porcel JM, Janssen J, Froudarakis M, Subotic D, Astoul P, Licht P, Schmid R, Scherpereel A, Rahman NM, Cardillo $G$ and Maskell NA: ERS/EACTS statement on the management of malignant pleural effusions. Eur Respir J 52(1): 1800349, 2018. PMID: 30054348. DOI: 10.1183/ 13993003.00349-2018

27 Froudarakis ME, Klimathianaki M and Pougounias M: Systemic inflammatory reaction after thoracoscopic talc poudrage. Chest 129(2): 356-361, 2006. PMID: 16478852. DOI: 10.1378/chest. 129.2 .356

28 Siegel RD and Schiffman FJ: Systemic toxicity following intracavitary administration of bleomycin. Chest 98(2): 507, 1990. PMID: 1695874. DOI: 10.1378/chest.98.2.507

29 Alberts DS, Surwit EA, Peng YM, McCloskey T, Rivest R, Graham V, McDonald L and Roe D: Phase I clinical and pharmacokinetic study of mitoxantrone given to patients by intraperitoneal administration. Cancer Res 48(20): 5874-5877, 1988. PMID: 3167842.

30 Schmidt M, Schaarschmidt G and Chemaissani A: [Pleurodesis in malignant pleural effusion: bleomycin $v s$. mitoxantrone]. Pneumologie 51(4): 367-372, 1997. PMID: 9221383.

31 Bjermer L, Gruber A, Sue-Chu M, Sandström T, Eksborg S and Henriksson R: Effects of intrapleural mitoxantrone and mepacrine on malignant pleural effusion - a randomised study. Eur J Cancer 31A(13-14): 2203-2208, 1995. PMID: 8652243. DOI: 10.1016/0959-8049(95)00425-4

32 Yildirim H, Metintas M, Ak G, Metintas S and Erginel S: Predictors of talc pleurodesis outcome in patients with malignant pleural effusions. Lung Cancer 62(1): 139-144, 2008. PMID: 18403045. DOI: 10.1016/j.lungcan.2008.02.017 
33 Santos PS, Marques MA, Cruz C, Monteiro H and Fradinho F: Predictors of talc slurry pleurodesis success in patients with malignant pleural effusions. Rev Port Pneumol (2006) 23(4): 216-220, 2017. PMID: 28606378. DOI: 10.1016/j.rppnen. 2017.01.008

34 Hassan M, Gadallah M, Mercer RM, Harriss E and Rahman NM: Predictors of outcome of pleurodesis in patients with malignant pleural effusion: a systematic review and metaanalysis. Expert Rev Respir Med 14(6): 645-654, 2020. PMID: 32213100. DOI: 10.1080/17476348.2020.1746647

35 Mercer RM, Macready J, Jeffries H, Speck N, Kanellakis NI, Maskell NA, Pepperell J, Saba T, West A, Ali N, Corcoran JP, Hallifax RJ, Psallidas I, Asciak R, Hassan M, Miller RF and Rahman NM: Clinically important associations of pleurodesis success in malignant pleural effusion: Analysis of the TIME1 data set. Respirology 25(7): 750-755, 2020. PMID: 31846131. DOI: $10.1111 /$ resp.13755

36 Yeung M, Loh EW, Tiong TY and Tam KW: Indwelling pleural catheter versus talc pleurodesis for malignant pleural effusion: a meta-analysis. Clin Exp Metastasis 37(4): 541-549, 2020. PMID: 32524317. DOI: $10.1007 / \mathrm{s} 10585-020-10042-2$

37 Grosu HB, Lu W, Ost DE, Vial MR, Hernandez M, Ghosh N, Noor L, Hasan AM, Bashoura L, Faiz S, Balachandran D, Casal R, Eapen G, Shannon V, Sheshadri A, Tang X, Rahman N and Wistuba II: Pleural fluid cytokine levels at baseline and over time are associated with time to IPC removal: an exploratory study. J Bronchology Interv Pulmonol 27(1): 4-13, 2020. PMID: 31373905. DOI: 10.1097/LBR.0000000000000602
38 van den Heuvel MM, Smit HJ, Barbierato SB, Havenith CE, Beelen RH and Postmus PE: Talc-induced inflammation in the pleural cavity. Eur Respir J 12(6): 1419-1423, 1998. PMID: 9877502. DOI: 10.1183/09031936.98.12061419

39 Hsu LH, Soong TC, Chu NM, Huang CY, Kao SH and Lin YF: The inflammatory cytokine profile of patients with malignant pleural effusion treated with pleurodesis. J Clin Med 9(12): 4010, 2020. PMID: 33322487. DOI: 10.3390/jcm9124010

40 Schwarz Y and Star A: Role of talc modulation on cytokine activation in cancer patients undergoing pleurodesis. Pulm Med 2012: 806183, 2012. PMID: 22536501. DOI: 10.1155/ 2012/806183

41 Purdy M, Kokki M, Anttila M, Aspinen S, Juvonen P, Korhonen R, Selander T, Kokki H and Eskelinen M: Does the rectus sheath block analgesia reduce the inflammatory response biomarkers' IL-1ra, IL-6, IL-8, IL-10 and IL-1 $\beta$ concentrations following surgery? A randomized clinical trial of patients with cancer and benign disease. Anticancer Res 36(6): 3005-3011, 2016. PMID: 27272818 .
Received March 22, 2021

Revised April 18, 2021

Accepted April 20, 2021 